\title{
Dampak Fenomena El Nino dan La Nina Terhadap Keseimbangan Air Lahan Pertanian dan Periode Tumbuh Tersedia di Daerah Waeapo Pulau Buru
}

\author{
The Impact of El Nino and La Nina Phenomenon's on the Balance of Agricultural Water and \\ Growth Periods Available in Waeapo Region of Buru Island
}

\author{
Siti Lailatul Nangimah", Samuel Laimeheriwa,", ${ }^{2}$,eny Tomasoa ${ }^{2}$ \\ ${ }^{1}$ Program Studi Agroteknologi, Jurusan Budidaya Pertanian, Fakultas Pertanian, Universitas Pattimura \\ J1. Ir. M. Putuhena, Kampus Poka Ambon 97233 \\ ${ }^{2}$ Jurusan Budidaya Pertanian, Fakultas Pertanian, Universitas Pattimura \\ Jl. I. M. Puttuhena, Kampus Poka Ambon 97233 \\ Korespondensi: e-mail: laimeheriwasamuel@yahoo.co.id
}

\begin{abstract}
The study aimed to determine the years of events El Nino and La Nina, analyze the effects of El Nino and La Nina events on water balance, and determine the available growing periods in Waeapo areas under various rainfall conditions. Climate data analysis was carried out with the following stages: a) generation of rainfall data; $b$ ) analysis of extreme rainfall of El Nino and La Nina; c) calculation of land water balance using the Thornthwaite-Mather method; and d) determination of available growing period under various rainfall conditions. The results showed that in the last 30 years in the Waeapo area, there were eight times of a phenomenon of extreme dry rainfall (El-Nino), with an average intensity of once every three years. The phenomenon of extreme wet rainfall (La-Nina) occurred six times with an average intensity of once every five years. Based on the calculation of land water balance, during El-Nino rainfall conditions, there was an annual groundwater deficit of $403 \mathrm{~mm}$ or 172\% of normal conditions, whereas during La-Nina rainfall conditions there was a surplus of annual groundwater of $775 \mathrm{~mm}$ or $222 \%$ of normal conditions. When an ElNino phenomenon occurred, the available growing period was only five months (January to May), and when the LaNina phenomenon occurred, the growing period was available throughout the year (12 months).
\end{abstract}

Keywords: El Nino, La Nina, land water balance, available growing period, Buru Island

\section{ABSTRAK}

Penelitian bertujuan untuk menentukan tahun-tahun kejadian El Nino dan La Nina, menganalisis dampak kejadian El Nino dan La Nina terhadap neraca air lahan, dan menetapkan periode tumbuh tersedia di daerah Waeapo pada berbagai kondisi curah hujan. Analisis data iklim dilakukan dengan tahapan sebagai berikut: a) pembangkitan data curah hujan; b) analisis curah hujan ekstrim El Nino dan La Nina; c) perhitungan neraca air lahan menggunakan metode Thornthwaite-Mather; dan d) penentuan periode tumbuh tersedia pada berbagai kondisi curah hujan. Hasil penelitian menunjukkan bahwa dalam periode 30 tahun terakhir di Daerah Waeapo sudah terjadi fenomena curah hujan ekstrem kering (El Nino) sebanyak delapan kali, dengan intensitas rata-rata tiga tahun sekali. Dan fenomena curah hujan ekstrem basah (La Nina) terjadi sebanyak enam kali dengan intensitas rata-rata lima tahun sekali. Berdasarkan perhitungan neraca air lahan, pada kondisi curah hujan El Nino terjadi defisit air tanah tahunan sebesar $403 \mathrm{~mm}$ atau $172 \%$ dari kondisi normalnya, sebaliknya pada kondisi curah hujan La Nina terjadi surplus air tanah tahunan sebesar $775 \mathrm{~mm}$ atau $222 \%$ dari kondisi normalnya. Ketika terjadi fenomena El Nino periode tumbuh yang tersedia hanya lima bulan (Januari s.d Mei), dan ketika terjadi fenomena La-Nina periode tumbuh berlangsung sepanjang tahun (12 bulan).

Kata kunci: El Nino, La Nina, neraca air lahan, periode tumbuh tersedia, Pulau Buru

\section{PENDAHULUAN}

Iklim/cuaca merupakan salah satu komponen ekosistem yang sangat dinamik dan sulit dikendalikan sesuai kebutuhan. Karena sifatnya yang dinamis, beragam, dan terbuka maka pendekatan terhadap iklim/cuaca agar lebih berdayaguna dalam berbagai bidang kehidupan, diperlukan suatu pemahaman yang lebih akurat terhadap karakteristik iklim melalui analisis dan interpretasi data iklim. Hasil analisis dan interpretasi data iklim dapat berupa informasi yang aplikatif dalam berbagai bidang kehidupan.

Indonesia memiliki wilayah yang luas dan beragam dan setiap daerah memiliki keadaan yang khas, 
termasuk keadaan iklim. Hal ini menyebabkan interaksi antara tanaman dengan kondisi iklim berbeda antara suatu tempat dengan tempat lainnya. Informasi keaadaan iklim suatu tempat memegang peranan penting bagi bentuk dan pengembangan pertanian tempat tersebut; karena dengan memanfaatkan pengetahuan tentang hubungan antara tanaman dan iklim dapatlah dibuat prakiraan waktu tanam, waktu panen, kejadian kekeringan (defisit air), banjir (surplus air), serangan hama dan penyakit, penentuan jenis tanaman yang sesuai, dan sebagainya.

Dari berbagai hasil penelitian menunjukkan bahwa akhir-akhir ini kejadian iklim ekstrim semakin sering terjadi baik dari sisi intensitas maupun frekuensinya, sementara itu ada kecenderungan sudah terjadi perubahan pola iklim dunia akibat pemanasan global (Kaimuddin, 2000; Boer et al., 2003). Menurut Las (2007), dampak negatif yang ditimbulkan akibat kejadian iklim ekstrim dan akibat perubahan iklim tersebut yaitu menurunnya produksi potensial pertanian akibat naiknya suhu, menurunnya ketersediaan air wilayah akibat kekeringan, meluasnya wilayah beresiko banjir dan longsor, kenaikan permukaan air laut, meningkatnya jumlah manusia yang terekspose terhadap penyakit menular, dan sebagainya. Disamping itu, Laimeheriwa (2015) menyebutkan bahwa dampak positif akibat perubahan iklim tersebut seperti meningkatnya jumlah curah hujan selama musim kemarau akan meningkatkan intensitas tanam; terutama pada wilayah-wilayah yang beriklim kering.

Berbagai proses yang memicu perubahan iklim dan cuaca ekstrim seperti El-Nino dan La-Nina telah diterima banyak pihak sebagai dampak pemanasan global, diantaranya berdampak langsung terhadap ketersediaan air wilayah; termasuk lahan pertanian. Dampak selanjutannya adalah perubahan waktu dan pola tanam serta intensitas tanam karena berubahnya masa tanam atau periode tumbuh tersedia akibat terjadinya pergeseran musim.

Kattenberg et al. (1976), melaporkan bahwa tingkat kerusakan akibat kekeringan dan kebanjiran pada tahun-tahun ENSO (El-Nino Southern Oscillation) pada beberapa dekade terakhir ini semakin meluas dan semakin berat. Terkait dengan hal tersebut di atas, maka kemampuan sistem untuk beradaptasi terhadap kejadian iklim ekstrem harus dibangun melalui upaya-upaya yang berkesinambungan agar dapat meningkatkan ketahanan sistem terhadap keragaman iklim masa datang.

Osok et al. (2017) melaporkan bahwa kejadian curah hujan ekstrim yang terjadi pada salah satu wilayah di Maluku dengan pola hujan moonson dalam periode 60 tahun terakhir (1957-2016) sebanyak 24 kali yang bertepatan dengan kejadian El-Nino dan La-Nina di Indonesia. El-Nino terjadi sebanyak 15 kali dengan intensitas 1-11 tahun sekali atau rata-rata 4 tahun sekali, dan La-Nina terjadi 9 kali dengan intensitas 1-13 tahun sekali atau rata-rata 5 tahun sekali. Kejadian curah ekstrim El-Nino tersebut akan menyebabkan penurunan kadar air tanah (defisit air) tahunan hingga $244 \%$ dari kondisi normalnya, dan pada pada saat La-Nina terjadi peningkatan kadar air tanah (surplus air) tahunan hingga $157 \%$ dari kondisi normalnya.

Penelitian ini bertujuan untuk: 1) menentukan tahun-tahun kejadian curah hujan ekstrim (El-Nino dan La-Nina) dan intensitasnya dalam periode 30 tahun terakhir di Daerah Waeapo; 2) menganalisis dampak kejadian curah hujan ekstrim terhadap neraca air lahan pertanian di Daerah Waeapo; dan 3) menetapkan periode tumbuh tersedia di Daerah Waeapo pada berbagai kondisi curah hujan.

\section{METODOLOGI PENELITIAN}

\section{Lokasi dan Waktu}

Penelitian ini dilaksanakan di wilayah Kabupaten Buru difokuskan pada daerah sentra produksi tanaman semusim (sayuran dan tanaman pangan), yaitu di daerah Waeapo yang berlangsung selama 2 bulan (SeptemberOktober 2018).

\section{Bahan dan Alat} adalah:

Bahan yang digunakan dalam penelitian ini

(1) Data curah hujan bulanan 30 tahun pengamatan (periode 1988-2017) yang tercatat di Stasiun Meteorologi Namlea dan Stasiun Hujan yang ada di daerah Waeapo,

(2) Data unsur iklim bulanan lainnya (suhu udara, kelembaban udara, lama penyinaran, dan angin) 15 tahun pengamatan (periode 2003-2017) yang tercatat di Stasiun Meteorologi Namlea.

(3) Data lainnya berupa: jenis tanah, jenis komoditi pertanian yang diusahakan petani, dan data penunjang lainnya.

Data yang tidak tersedia dibangkitkan melalui pendekatan statistik-matematik berdasarkan indikator fisik wilayah. Alat yang digunakan adalah: MS Word 2010, MS Excel 2010, komputer, dan alat tulis menulis.

\section{Pengumpulan Data}

Pengumpulan data pada penelitian ini terdiri dari data primer yang diperoleh melaui survey lapangan dan data sekunder yang diperoleh dari berbagai referensi ilmiah melalui studi kepustakaan, instansi terkait, maupun sumber lainnya yang relevan.

\section{Analisis Data}

\section{Membangkitkan data curah hujan}

Langkah membangkitkan data curah hujan dengan metode matematik sederhana sebagai berikut: 1) data yang digunakan adalah nilai rata-rata curah hujan bulanan untuk Daerah Waeapo yang tersedia dan Daerah Namlea; dimana tahun/periode data yang digunakan adalah sama untuk kedua daerah; 2) membandingkan/membagi nilai curah hujan rata-rata 
setiap bulannya dari kedua daerah tersebut; yaitu rasio antara daerah Waeapo dengan daerah Namlea; 3) asumsi dasar yang digunakan dalam membangkitkan data curah hujan adalah persentase/koefisien perubahan curah hujan bulanan sama pada kedua wilayah, dan data runut waktu curah hujan bulanan yang dibangkitkan untuk daerah Waeapo yang datanya tidak tersedia adalah proporsional dibandingkan dengan data runut waktu curah hujan pada daerah Namlea; dan 4) hasil pembagian dalam bentuk nilai/koefisien bulanan selanjutnya dikalikan dengan data runut waktu curah hujan bulanan Stasiun Meteorologi Namlea periode 1988-2017; khususnya untuk bulan atau tahun yang datanya tidak tersedia. Hasil perkalian berupa data runut waktu curah hujan bulanan untuk daerah Waeapo periode 1988-2017.

\section{Analisis curah hujan pada kondisi normal dan ekstrim}

Analisis menggunakan data time series curah hujan 30 tahun terakhir (periode 1988-2017). Penentuan kondisi curah hujan ekstrim setiap tahunnya berupa nilai curah hujan diatas normal dan dibawah normal serta jauh diatas normal dan jauh dibawah normal sesuai standar BMKG, yaitu: 1) curah hujan dibawah normal adalah curah hujan sebesar 0,70-0,85 dari nilai curah hujan rata-rata (normal); 2) curah hujan diatas normal adalah curah hujan sebesar 1,15-1,30 dari nilai curah hujan rata-rata (normal); 3) curah hujan jauh dibawah normal adalah curah hujan sebesar $<0,70$ dari nilai curah hujan rata-rata (normal); 4) curah hujan jauh diatas normal adalah curah hujan sebesar > 1,30 dari nilai curah hujan rata-rata (normal).

Kejadian curah hujan diatas dan dibawah normal serta jauh diatas dan jauh dibawah normal setiap tahunnya kemudian disesuiakan dengan tahun-tahun kejadian El-Nino dan La-Nina di Indonesia untuk menentukan tahun-tahun kejadian El-Nino dan La Nina di Daerah Waeapo.

\section{Analisis neraca air lahan}

Analisis neraca air lahan menggunakan metode Thornthwaite dan Mather (1957) mengikuti langkahlangkah, sebagai berikut:

a. Menyusun tabel isian neraca air bulanan

b. Mengisi kolom curah hujan, $\mathrm{CH}$

c. Mengisi kolom suhu udara, T

d. Mengisi kolom evapotranspirasi potensial, ETp

e. Menghitung nilai $\mathrm{CH}-\mathrm{ETp}$

f. Hasil negatif pada langkah (e) diakumulasikan bulan demi bulan sebagai APWL (akumulasi air yang hilang secara potensial) dan diisi pada kolom yang bersangkutan

g. Menentukan nilai kapasitas lapang (KL), titik layu permanen (TLP) serta kedalaman tinjau $1 \mathrm{~m}$, yaitu kedalaman perakaran maksimum untuk tanaman umur pendek atau semusim.

h. Mengisi kolom kandungan air tanah (KAT), dimulai dari awal terjadinya APWL hingga APWL terakhir. i. Untuk menentukan nilai KAT (awal APWL dan seterusnya) dihitung dengan persamaan :

$\mathrm{KSA}=\mathrm{WHC} \times \mathrm{k}^{\mid \mathrm{APWL}} \mid ; \mathrm{WHC}=\mathrm{KL}-\mathrm{TLP} ; \mathrm{WHC}$ = AT; air tersedia; KAT $=$ TLP + KSA

dimana $\mathrm{KSA}=$ ketersediaan air tanah aktual, WHC

= kapasitas simpan air tanah, dan $\mathrm{k}=$ tetapan yang nilainya dihitung dengan persamaan: $\mathrm{k}=$ po + pi/WHC; dimana po $=1,000412351$ dan $\mathrm{p} 1=$ 1,073807306 .

j. Mengisi kolom perubahan kandungan air tanah (dKAT)

k. Mengisi kolom evapotranspirasi actual

1. Mengisi kolom defisit, $\mathrm{D}=\mathrm{ETp}-\mathrm{ETa}$

m. Mengisi kolom surplus, $\mathrm{S}=\mathrm{CH}-\mathrm{ETp}-\mathrm{dKAT}$

\section{Penentuan periode tumbuh tersedia}

Penetapan periode tumbuh di daerah Waeapo didasarkan pada hasil perhitungan neraca air lahan pada berbagai kondisi curah hujan, dengan tiga kriteria penentuannya, sebagai berikut: 1) Periode dimana kadar air tanah berada dalam kondisi optimum bagi pertumbuhan:

dimana KATopt $=\mathrm{KAT} \geq \mathrm{TLP}+0,5 \times \mathrm{WHC}$

2) Bulan/periode dimana tidak terjadi defisit air; dan 3 ) Rasio antara curah hujan $(\mathrm{CH})$ dengan evapotranspirasi potensial (ETp); jika pada bulan tertentu yaitu 1 (satu) bulan sebelum dan sesudah periode KATopt $\mathrm{CH} / \mathrm{ETp} \geq$ 0,75, maka bulan tersebut masuk dalam periode tumbuh tersedia. Penetapan waktu 1 (satu) bulan sebelum dan sesudah periode KATopt berdasarkan pertimbangan bahwa pada tahap awal dan akhir perkembangan tanaman, kebutuhan air relatif sedikit dibandingkan tahap perkembangan tanaman lainnya. Dengan demikian bulan-bulan yang memenuhi kriteria $\mathrm{CH} / \mathrm{ETp}$ $\geq 0,75 \mathrm{CH} / \mathrm{ETp} \geq 0,75$ merupakan awal atau akhir periode tumbuh tersedia.

\section{HASIL DAN PEMBAHASAN}

\section{Keadaan Umum Lokasi Penelitian}

\section{Letak dan luas}

Secara administratif pemerintahan, Waeapo merupakan salah satu dari 10 kecamatan yang ada di wilayah Kabupaten Buru yang terletak di bagian utara Pulau Buru. Letak Kecamatan Waeapo secara astronomis berada pada posisi $03^{\circ} 12^{\prime} 07^{\prime \prime}-03^{\circ} 23^{\prime} 41^{\prime \prime}$ Lintang Selatan dan $126^{\circ} 53^{\prime} 01^{\prime \prime}-127^{\circ} 02^{\prime} 41^{\prime \prime}$ Bujur Timur, dengan batas-batas geografis wilayah sebagai berikut (BPS, 2017): sebelah utara Kecamatan Lilialy dan Kecamatan Waplau; sebelah selatan Kecamatan Waelata dan Kecamatan Teluk Kayeli; sebeah barat Kecamatan Lolong Guba; dan sebelah timur Kecamatan Namlea dan Laut Teluk Kayeli.

\section{Biofisik wilayah}

\section{Tanah}

Berdasarkan hasil penelitian lapangan dan merujuk pada Sistem Klasifikasi Tanah Nasional dan 
Peta Landsystem Pulau Buru Provinsi Maluku skala 1:250.000, jenis tanah yang umumnya ditemukan di Daerah Waeapo adalah Aluvial, Gleisol (bahan induk aluvium), dan Kambisol (bahan induk metamorf). Jenisjenis tanah ini bertekstur mulai dari lempung hingga liat berdebu (Tim Amdal Unpatti, 2017).

Tabel 2 menunjukkan bahwa di Kecamatan Waeapo saat ini umumnya diusahakan lima jenis komoditi tanaman pangan, 11 komoditi sayuran, 10 komoditi buahan, dan enam komoditi tanaman perkebunan. Nampak bahwa, daerah Kecamatan Waeapo merupakan sentra produksi utama (produksi tertinggi) tanaman pangan; khususnya padi sawah dan tanaman hortikultura sayuran tomat, ketimun, buncis serta tanaman hortikultura buahan alpukat, jeruk siam, mangga, dan semangka.

\section{Distribusi Tahunan dan Kondisi Ekstrem Curah Hujan Daerah Waeapo}

\section{Distribusi curah hujan tahunan}

Nampak pada Gambar 1, selama periode 30 tahun telah terjadi penyimpangan curah hujan $(\mathrm{CH})$ kurang dari kondisi normal sebanyak 10 kali; 8 kali diantaranya termasuk $\mathrm{CH}$ dibawah normal, dan 2 kali termasuk $\mathrm{CH}$ jauh dibawah normal (ekstrem kering). Selanjutnya, penyimpangan $\mathrm{CH}$ melebihi kondisi normalnya sebanyak 10 kali; lima kali diantaranya termasuk $\mathrm{CH}$ diatas normal dan lima kali termasuk $\mathrm{CH}$ jauh diatas normal (ekstrem basah). Dengan demikian dalam periode 30 tahun tersebut, terjadi penyimpangan $\mathrm{CH}$ dari kondisi normalnya sebanyak $66,7 \%$ dan $\mathrm{CH}$ berada pada selang normalnya $33,3 \%$.

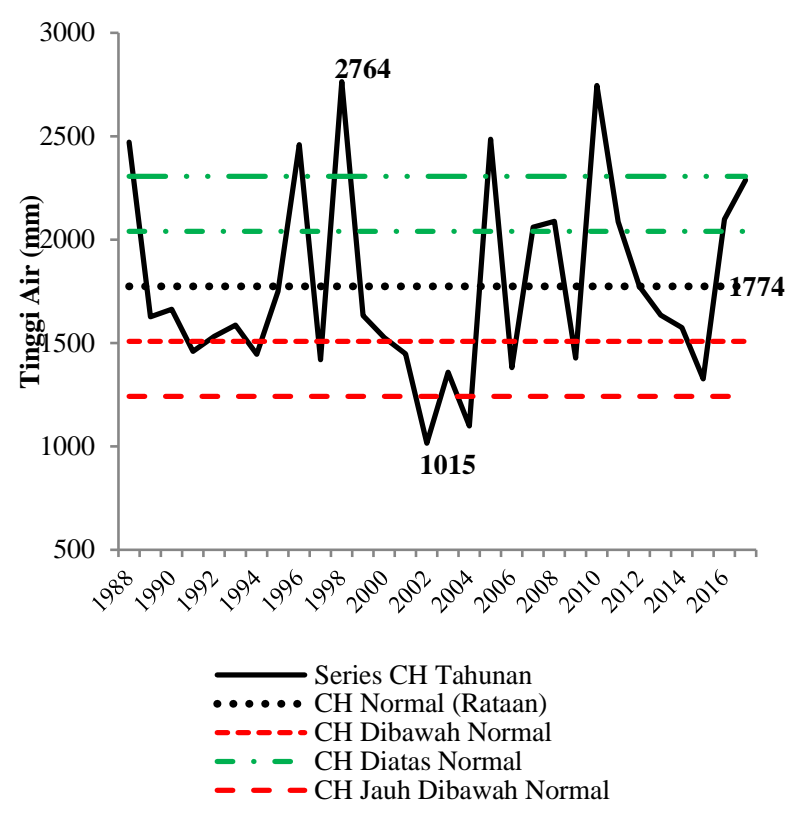

Gambar 1. Distribusi curah hujan $(\mathrm{CH})$ tahunan di Daerah Waeapo

\section{Kondisi pertanian}

\section{Curah hujan ekstrem El-Nino dan La-Nina}

Terlihat pada Tabel 3, penurunan curah hujan dari kondisi normalnya selama kejadian El-Nino yang biasanya terjadi dalam periode April-Desember berlangsung tiap bulannya sebesar 11-140 mm per bulan atau 13-95\%. Presentase penurunan terbesar berlangsung dalam bulan Juni hingga September dengan kisaran 66-95\%.

Tabel 1. Kondisi iklim Daerah Waeapo

\begin{tabular}{cccccccc}
\hline \multirow{2}{*}{ Bulan } & $\begin{array}{c}\text { Curah Hujan } \\
(\mathrm{mm})\end{array}$ & \multicolumn{3}{c}{ Suhu Udara $\left({ }^{\circ} \mathrm{C}\right)$} & $\begin{array}{c}\text { Kelembaban } \\
\text { Nisbi }(\%)\end{array}$ & $\begin{array}{c}\text { Lama } \\
\text { Penyinaran }(\%)\end{array}$ & $\begin{array}{c}\text { Kecepatan } \\
\text { Angin }(\mathrm{knot})\end{array}$ \\
\cline { 2 - 5 } Januari & 294 & 26,7 & 30,7 & 24,1 & 86,9 & 53,1 & 5,3 \\
Februari & 273 & 26,7 & 30,6 & 24,0 & 87,1 & 56,7 & 5,3 \\
Maret & 235 & 26,7 & 30,9 & 24,0 & 86,9 & 60,5 & 5,7 \\
April & 161 & 27,0 & 31,2 & 23,9 & 85,6 & 67,6 & 5,2 \\
Mei & 84 & 27,1 & 31,3 & 23,8 & 84,7 & 74,4 & 6,5 \\
Juni & 108 & 26,4 & 30,7 & 23,5 & 84,3 & 62,4 & 7,1 \\
Juli & 76 & 25,9 & 30,0 & 22,9 & 83,8 & 60,2 & 8,1 \\
Agustus & 62 & 25,9 & 30,2 & 22,5 & 79,7 & 72,3 & 8,9 \\
September & 34 & 26,6 & 31,3 & 23,0 & 78,2 & 76,4 & 8,1 \\
Oktober & 53 & 27,4 & 32,1 & 23,3 & 78,9 & 83,0 & 7,1 \\
Nopember & 146 & 27,6 & 32,3 & 24,0 & 80,5 & 81,9 & 6,0 \\
Desember & 248 & 27,3 & 31,4 & 24,1 & 84,7 & 64,5 & 6,1 \\
\hline Tahunan & $\mathbf{1 7 7 4}$ & $\mathbf{2 6 , 8}$ & $\mathbf{3 1 , 1}$ & $\mathbf{2 3 , 6}$ & $\mathbf{8 3 , 5}$ & $\mathbf{6 7 , 8}$ & $\mathbf{6 , 6}$ \\
\hline
\end{tabular}

Sumber: Data iklim Stasiun Meteorologi Namlea (yang diolah tahun 2018) 
Tabel 2. Produksi pertanian Kecamatan Waeapo

\begin{tabular}{|c|c|c|c|c|c|}
\hline \multirow{2}{*}{$\begin{array}{c}\text { No } \\
\text {. }\end{array}$} & \multirow{2}{*}{ Komoditi } & \multicolumn{2}{|c|}{ Produksi (ton) } & \multirow{2}{*}{$\begin{array}{l}\text { Kontribusi ke } \\
\text { Kab.Buru (\%) }\end{array}$} & \multirow{2}{*}{ Keterangan } \\
\hline & & Kec. Waeapo & Kab. Buru & & \\
\hline A. & Tanaman Pangan & & & & \\
\hline 1. & $\overline{\text { Padi Sawah *) }}$ & 31.865 & 53.066 & 60,0 & Prod. tertinggi dari 4 kec. yg berproduksi \\
\hline 2. & Ubi Jalar & 45 & 8.267 & 0,5 & Prod. tertinggi ke- 9 dari $10 \mathrm{kec}$. yg berproduksi \\
\hline 3. & Jagung & 5 & 1.610 & 0,3 & Prod. terendah dari $8 \mathrm{kec}$. yg berproduksi \\
\hline 4. & Kacang Tanah & 13 & 361 & 3,6 & Prod. tertinggi ke-6 dari 9 kec. yg berproduksi \\
\hline 5. & Kedelai & 2 & 81 & 2,5 & Prod. terendah dari 4 kec. yg berproduksi \\
\hline B. & $\underline{\text { Sayuran }}$ & & & & \\
\hline 1. & $\overline{\text { Bawang Merah }}$ & 51 & 265 & 19,2 & Prod. tertinggi ke-3 dari $10 \mathrm{kec}$. yg berproduksi \\
\hline 2. & Cabe Besar & 106 & 512 & 20,7 & Prod. tertinggi ke-2 dari $10 \mathrm{kec}$. yg berproduksi \\
\hline 3. & Cabe Rawit & 72 & 474 & 15,2 & Prod. tertinggi ke- 2 dari $10 \mathrm{kec}$. yg berproduksi \\
\hline 4. & Tomat $*)$ & 138 & 452 & 30,5 & Prod. tertinggi dari $10 \mathrm{kec}$. yg berproduksi \\
\hline 5 . & Ketimun *) & 689 & 1.512 & 45,6 & Prod. tertinggi dari 9 kec. yg berproduksi \\
\hline 6. & Terung & 64 & 299 & 21,4 & Prod. tertinggi ke-3 dari $10 \mathrm{kec}$. yg berproduksi \\
\hline 7. & Kacang Panjang & 62 & 448 & 13,8 & Prod. tertinggi ke-3 dari $10 \mathrm{kec}$. yg berproduksi \\
\hline 8. & Buncis *) & 63 & 161 & 39,1 & Prod. tertinggi dari $8 \mathrm{kec}$. yg berproduksi \\
\hline 9. & Bayam & 39 & 357 & 10,9 & Prod. tertinggi ke-3 dari $10 \mathrm{kec}$ yg berproduksi \\
\hline 10 & Labu Siam & 4 & 76 & 5,3 & Prod. tertinggi ke-5 dari 6 kec. yg berproduksi \\
\hline 11. & Kangkung & 25 & 315 & 7,9 & Prod. tertinggi ke-7 dari $10 \mathrm{kec}$. yg berproduksi \\
\hline C. & $\underline{\text { Buahan }}$ & & & & \\
\hline 1. & Alpukat $*$ ) & 170 & 777 & 21,9 & Prod. tertinggi dari 9 kec. yg berproduksi \\
\hline 2. & Jeruk Siam *) & 10873 & 15.524 & 70,0 & Prod. tertinggi dari $10 \mathrm{kec}$ yg berproduksi \\
\hline 3. & Mangga *) & 868 & 2.729 & 31,8 & Prod. tertinggi dari $10 \mathrm{kec}$. yg berproduksi \\
\hline 4. & Durian & 71 & 934 & 7,6 & Prod. tertinggi ke-6 dari 7 kec. yg berproduksi \\
\hline 5 . & Pepaya & 691 & 3.439 & 20,1 & Prod. tertinggi ke- 2 dari $10 \mathrm{kec}$. yg berproduksi \\
\hline 6. & Pisang & 3914 & 42.727 & 9,2 & Prod. tertinggi ke-5 dari $10 \mathrm{kec}$ yg berproduksi \\
\hline 7. & Rambutan & 51 & 125 & 40,8 & Prod. tertinggi ke-2 dari 2 kec. yg berproduksi \\
\hline 8. & Buah Naga & 53 & 193 & 27,5 & Prod. tertinggi ke- 2 dari 4 kec. yg berproduksi \\
\hline 9. & Melon & 12 & 50 & 24,0 & Prod. tertinggi ke- 2 dari $3 \mathrm{kec}$. yg berproduksi \\
\hline 10. & Semangka *) & 75 & 84 & 89,3 & Prod. tertinggi dari $2 \mathrm{kec}$. yg berproduksi \\
\hline D. & Perkebunan & & & & \\
\hline 1. & Kelapa & 52 & 3.643 & 1,4 & Prod. terendah dari $10 \mathrm{kec} . \mathrm{yg}$ berproduksi \\
\hline 2. & Pala & 1 & 34 & 2,9 & Prod. tertinggi ke-5 dari 6 kec. yg berproduksi \\
\hline 3. & Kakao & 133 & 3.617 & 3,7 & Prod. tertinggi ke-7 dari $10 \mathrm{kec}$. yg berproduksi \\
\hline 4. & Cengkeh & 2 & 448 & 0,4 & Prod. terendah dari 7 kec. yg berproduksi \\
\hline 5 . & Kopi & 2 & 68 & 2,9 & Prod. terendah dari 7 kec. yg berproduksi \\
\hline 6. & Jambu Mete & 3 & 640 & 0,5 & Prod. terendah dari $10 \mathrm{kec}$. yg berproduksi \\
\hline
\end{tabular}

Sumber: Dimodifikasi dari BPS (2017)

Keterangan: *) komoditi yang produksinya tertinggi dari semua kecamatan di Kabupaten Buru

Tabel 3. Curah hujan selama dua tahun kejadian El-Nino paling ekstrem di Daerah Waeapo selama 30 tahun periode 1988-2017

\begin{tabular}{|c|c|c|c|c|c|c|c|c|c|c|c|c|c|}
\hline \multirow{2}{*}{ Tahun } & \multicolumn{13}{|c|}{ Curah Hujan (mm) } \\
\hline & Jan & Feb & Mar & Apr & Mei & Jun & $\mathrm{Jul}$ & Ags & Sep & Okt & Nov & Des & Setahun \\
\hline 2002 & 322 & 212 & 140 & 75 & 55 & 22 & 16 & 6 & 8 & 10 & 40 & 109 & 1015 \\
\hline 2004 & 183 & 282 & 100 & 150 & 89 & 53 & 10 & 0 & 10 & 69 & 46 & 106 & 1098 \\
\hline Rata-rata & 252 & 247 & 121 & 113 & 72 & 37 & 13 & 3 & 9 & 39 & 43 & 108 & 1057 \\
\hline \multicolumn{14}{|c|}{ Penyimpangan dari kondisi normal } \\
\hline $\mathrm{Mm}$ & -42 & -26 & -115 & -48 & -11 & -71 & -63 & -59 & -25 & -14 & -103 & -140 & -717 \\
\hline$\%$ & -14 & -10 & -49 & -30 & -13 & -66 & -83 & -95 & -73 & -26 & -71 & -57 & -40 \\
\hline
\end{tabular}

Tabel 4 menunjukkan bahwa peningkatan curah hujan dari kondisi normal selama kejadian La-Nina yang biasanya terjadi dalam periode April-Desember berlangsung tiap bulannya sebesar 10-125 mm atau 14199\%. Presentase peningkatan curah hujan terbesar berlangsung dalam bulan Mei-Juni dan AgustusSeptember dengan kisaran 96-199\%. Nampak bahwa dari 8 tahun kejadian El-Nino, sebanyak empat kali kejadiannya selalu diikuti oleh kejadian La-Nina; yaitu pada tahun 1997-1998, 2006-2007, 2009-2010, dan 2015-2016. 
Tabel 4. Curah hujan selama dua tahun kejadian La-Nina paling ekstrem di Daerah Waeapo selama 30 tahun periode 1988-2017

\begin{tabular}{cccccccccccccc}
\hline Tahun & \multicolumn{10}{c}{ Curah Hujan $(\mathbf{m m})$} \\
\cline { 2 - 16 } & Jan & Feb & Mar & Apr & Mei & Jun & Jul & Ags & Sep & Okt & Nov & Des & Setahun \\
\hline 1998 & 291 & 305 & 385 & 397 & 173 & 207 & 71 & 119 & 92 & 63 & 291 & 370 & 2764 \\
2010 & 401 & 281 & 369 & 178 & 171 & 215 & 101 & 256 & 97 & 100 & 246 & 331 & 2744 \\
Rata-rata & 346 & 293 & 377 & 288 & 172 & 211 & 86 & 187 & 95 & 81 & 268 & 350 & 2754 \\
\hline \multicolumn{10}{c}{ Penyimpangan dari kondisi normal } \\
mm & 52 & 20 & 142 & 127 & 89 & 103 & 10 & 125 & 61 & 28 & 122 & 102 & 980 \\
$\%$ & 18 & 7 & 60 & 78 & 107 & 96 & 14 & 199 & 181 & 53 & 83 & 41 & 55 \\
\hline
\end{tabular}

Tabel 5. Perhitungan neraca air lahan pada kondisi curah hujan rata-rata

\begin{tabular}{lcccccccccc}
\hline \multicolumn{1}{c}{ Bulan } & CH & T & ETp & CH-ETp & APWL & KAT & dKAT & ETa & D & S \\
\hline Januari & 294 & 26.7 & 138 & 156 & & 357 & 60 & 138 & 0 & 96 \\
Februari & 273 & 26.7 & 138 & 135 & & 357 & 0 & 138 & 0 & 135 \\
Maret & 235 & 26.7 & 138 & 97 & & 357 & 0 & 138 & 0 & 97 \\
April & 161 & 27.0 & 140 & 21 & & 357 & 0 & 140 & 0 & 21 \\
Mei & 84 & 27.1 & 141 & -57 & -57 & 308 & -49 & 133 & 8 & 0 \\
Jun & 108 & 26.4 & 135 & -27 & -84 & 289 & -19 & 127 & 8 & 0 \\
Juli & 76 & 25.9 & 131 & -55 & -139 & 259 & -30 & 106 & 25 & 0 \\
Agustus & 62 & 25.9 & 131 & -69 & -208 & 231 & -28 & 90 & 41 & 0 \\
September & 34 & 26.6 & 137 & -103 & -311 & 204 & -27 & 61 & 76 & 0 \\
Oktober & 53 & 27.4 & 143 & -90 & -401 & 190 & -14 & 67 & 76 & 0 \\
November & 146 & 27.6 & 145 & 1 & & 191 & 1 & 145 & 0 & 0 \\
Desember & 248 & 27.3 & 142 & 106 & & 297 & 106 & 142 & 0 & 0 \\
\hline Setahun & 1774 & 26.8 & 1659 & & & & 0 & 1425 & 234 & 349 \\
\hline
\end{tabular}

Keterangan: 1) Kedalaman tinjau: $1 \mathrm{~m}$; Tekstur tanah: lempung hingga liat berdebu; Kapasitas lapang: $357 \mathrm{~mm}$; Titik layu permanen: $167 \mathrm{~mm}$; Water holding capacity: $190 \mathrm{~mm}$; KATopt: $262 \mathrm{~mm}$; dan 2) $\mathrm{CH}=$ curah hujan (mm); $\mathrm{T}=$ suhu udara $\left({ }^{\circ} \mathrm{C}\right) ; \mathrm{ETp}=$ evapotranspirasi potensial $(\mathrm{mm}) ; \mathrm{APWL}=$ akumulasi air yang hilang secara potensial $(\mathrm{mm})$; KAT = kandungan air tanah $(\mathrm{mm})$; dKAT $=$ perubahan kandungan air tanah $(\mathrm{mm})$; Eta $=$ evapotranspirasi aktual $(\mathrm{mm})$; D = defisit air (mm); $\mathrm{S}=$ surplus air (mm).

Tabel 6. Perhitungan neraca air lahan pada kondisi curah hujan ekstrem kering (El-Nino)

\begin{tabular}{lcccccccccc}
\hline \multicolumn{1}{c}{ Bulan } & CH & T & ETp & CH-ETp & APWL & KAT & dKAT & Eta & D & S \\
\hline Januari & 252 & 26.7 & 138 & 114 & & 283 & 114 & 138 & 0 & 0 \\
Februari & 247 & 26.7 & 138 & 109 & & 357 & 74 & 138 & 0 & 35 \\
Maret & 121 & 26.7 & 138 & -17 & -17 & 341 & -16 & 137 & 1 & 0 \\
April & 113 & 27.0 & 140 & -27 & -44 & 318 & -23 & 136 & 4 & 0 \\
Mei & 72 & 27.1 & 141 & -69 & -113 & 272 & -46 & 118 & 23 & 0 \\
Jun & 37 & 26.4 & 135 & -98 & -211 & 230 & -42 & 79 & 56 & 0 \\
Juli & 13 & 25.9 & 131 & -118 & -329 & 201 & -29 & 42 & 89 & 0 \\
Agustus & 3 & 25.9 & 131 & -128 & -457 & 184 & -17 & 20 & 111 & 0 \\
September & 9 & 26.6 & 137 & -128 & -585 & 176 & -8 & 17 & 120 & 0 \\
Oktober & 39 & 27.4 & 143 & -104 & -689 & 172 & -4 & 43 & 100 & 0 \\
November & 43 & 27.6 & 145 & -102 & -791 & 170 & -2 & 45 & 100 & 0 \\
Desember & 108 & 27.3 & 142 & -34 & -825 & 169 & -1 & 109 & 33 & 0 \\
\hline Setahun & 1057 & 26.8 & 1659 & & & & 0 & 1022 & 637 & 35 \\
\hline Kerancy
\end{tabular}

Keterangan: Kedalaman tinjau: $1 \mathrm{~m}$; Tekstur tanah: lempung hingga liat berdebu; Kapasitas lapang: $357 \mathrm{~mm}$; Titik layu permanen: $167 \mathrm{~mm}$; Water holding capacity: $190 \mathrm{~mm}$; KATopt: $262 \mathrm{~mm}$; dan 2) $\mathrm{CH}=$ curah hujan (mm); $\mathrm{T}=$ suhu udara $\left({ }^{\circ} \mathrm{C}\right) ; \mathrm{ETp}=$ evapotranspirasi potensial $(\mathrm{mm}) ; \mathrm{APWL}=$ akumulasi air yang hilang secara potensial $(\mathrm{mm})$; KAT = kandungan air tanah $(\mathrm{mm})$; dKAT $=$ perubahan kandungan air tanah $(\mathrm{mm})$; Eta $=$ evapotranspirasi aktual $(\mathrm{mm})$; $\mathrm{D}=$ defisit air (mm); $\mathrm{S}=$ surplus air (mm). 
Tabel 7. Perhitungan neraca air lahan pada kondisi curah hujan ekstrem basah (La-Nina)

\begin{tabular}{lcccccccccc}
\hline \multicolumn{1}{c}{ Bulan } & CH & T & ETp & CH-ETp & APWL & KAT & dKAT & ETa & D & S \\
\hline Januari & 346 & 26.7 & 138 & 208 & & 357 & 0 & 138 & 0 & 208 \\
Februari & 293 & 26.7 & 138 & 155 & & 357 & 0 & 138 & 0 & 155 \\
Maret & 377 & 26.7 & 138 & 239 & & 357 & 0 & 138 & 0 & 239 \\
April & 288 & 27.0 & 140 & 148 & & 357 & 0 & 140 & 0 & 148 \\
Mei & 172 & 27.1 & 141 & 31 & & 357 & 0 & 141 & 0 & 31 \\
Jun & 211 & 26.4 & 135 & 76 & & 357 & 0 & 135 & 0 & 76 \\
Juli & 86 & 25.9 & 131 & -45 & -45 & 317 & -40 & 126 & 5 & 0 \\
Agustus & 187 & 25.9 & 131 & 56 & & 357 & 40 & 131 & 0 & 16 \\
September & 95 & 26.6 & 137 & -42 & -42 & 319 & -38 & 133 & 4 & 0 \\
Oktober & 81 & 27.4 & 143 & -62 & -104 & 277 & -42 & 123 & 20 & 0 \\
November & 268 & 27.6 & 145 & 123 & & 357 & 80 & 145 & 0 & 43 \\
Desember & 350 & 27.3 & 142 & 208 & & 357 & 0 & 142 & 0 & 208 \\
\hline Setahun & 2754 & 26.8 & 1659 & & & & 0 & 1630 & 29 & 1124 \\
\hline
\end{tabular}

Keterangan: 1) Kedalaman tinjau: $1 \mathrm{~m}$; Tekstur tanah: lempung hingga liat berdebu; Kapasitas lapang: $357 \mathrm{~mm}$; Titik layu permanen: $167 \mathrm{~mm}$; Water holding capacity: $190 \mathrm{~mm}$; KATopt: $262 \mathrm{~mm}$; dan 2) $\mathrm{CH}=$ curah hujan (mm); T = suhu udara $\left({ }^{\circ} \mathrm{C}\right) ; \mathrm{ETp}=$ evapotranspirasi potensial $(\mathrm{mm}) ; \mathrm{APWL}=$ akumulasi air yang hilang secara potensial $(\mathrm{mm}) ; \mathrm{KAT}=$ kandungan air tanah $(\mathrm{mm})$; dKAT $=$ perubahan kandungan air tanah $(\mathrm{mm}) ;$ Eta $=$ evapotranspirasi aktual $(\mathrm{mm}) ; \mathrm{D}=$ defisit air (mm); $\mathrm{S}=$ surplus air $(\mathrm{mm})$.

\section{Neraca Air Lahan}

Hasil perhitungan neraca air lahan Daerah Waeapo pada tiga kondisi curah hujan seperti yang disajikan pada Tabel 5, 6, dan 7. Tabel 5 menunjukkan bahwa pada kondisi curah hujan normal defisit air yang terjadi di Daerah Waeapo berlangsung selama 6 bulan (Mei s.d Oktober) dengan kisaran defisit antara 8-76 $\mathrm{mm} /$ bulan dengan total defisit $234 \mathrm{~mm} /$ tahun. Defisit air yang terjadi karena nilai potensial evapotrasnpirasi melebihi nilai aktualnya akibat curah hujan yang rendah. Sedangkan periode surplus air berlangsung selama 4 bulan, yaitu Januari sampai April dengan kisaran 21-135 mm dengan total surplus $349 \mathrm{~mm} /$ tahun. Surplus air yang terjadi selama musim hujan sangat bergantung pada selisih antara curah hujan dan evapotranspirasi potensial dan perubahan kadar air tanah tiap bulannya.

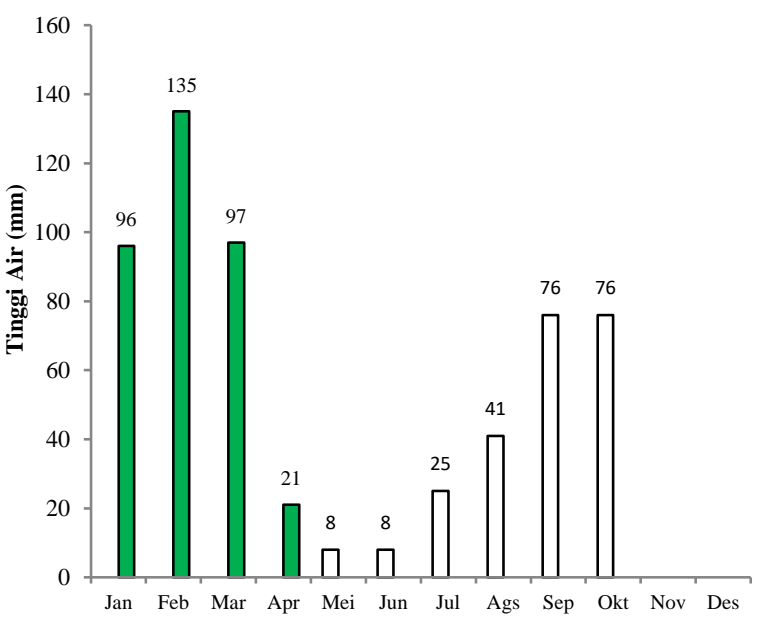

口Defisit Air (Mei s.d Oktober) घSurplus Air (Januari s.d April)

Gambar 2.Periode defisit dan surplus air di Daerah Waeapo pada kondisi curah hujan normal (rata-rata)

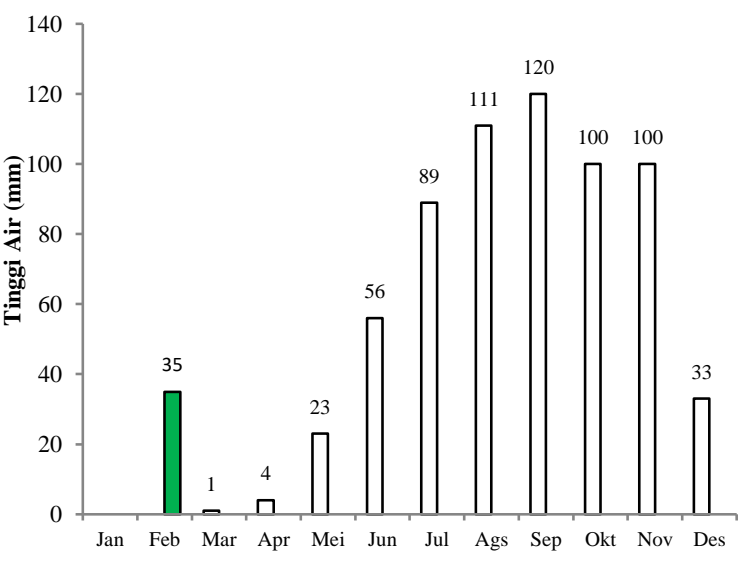

口Defisit Air (Maret s.d Desember) $\quad$ 口Surplus Air (Februari)

Gambar 3. Periode defisit dan surplus air di Daerah Waeapo pada saat El-Nino

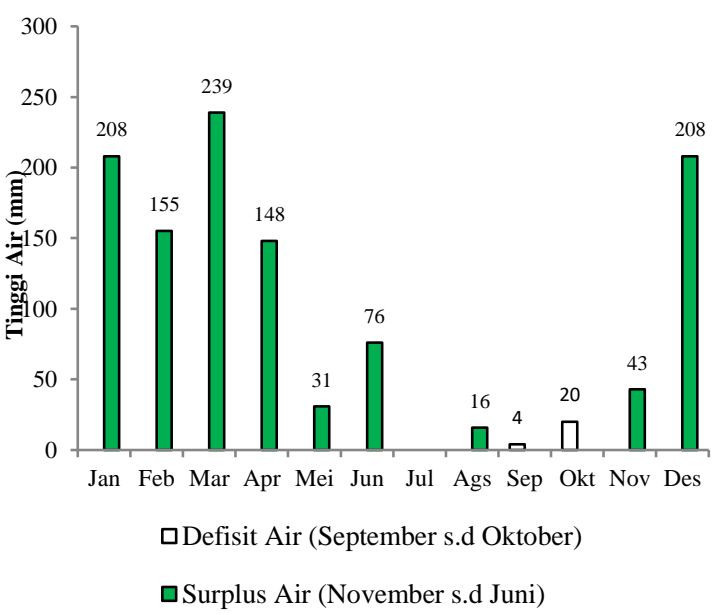

Gambar 4. Periode defisit dan surplus air di Daerah Waeapo pada saat La-Nina 
Secara grafis periode defisit dan surplus air tanah di Daerah Waeapo pada kondisi curah hujan normal seperti yang disajikan pada Gambar 2.

Hasil perhitungan neraca air lahan Daerah Waeapo pada kondisi curah hujan ekstrem El-Nino (Tabel 6) menunjukkan bahwa defisit air berlangsung selama 10 bulan (Maret s.d Desember) dengan kisaran defisit antara 1-120 mm/bulan dengan total defisit 637 $\mathrm{mm} /$ tahun; dimana 90,4\% diantaranya atau $576 \mathrm{~mm}$ berlangsung dalam periode Juni s.d November. Periode surplus air berlangsung hanya dalam 1 bulan, yaitu bulan Februari sebesar $35 \mathrm{~mm}$. Secara grafis periode defisit dan surplus air tanah di Daerah Waeapo pada kondisi El Nino seperti yang disajikan pada Gambar 3.

Selanjutnya, pada kondisi curah hujan ekstrem La Nina (Tabel 7), di Daerah Waeapo defisit air terjadi hanya dalam 3 bulan (Juli, September, dan Oktober) yang nilainya relatif kecil yaitu pada kisaran 4-20 mm per bulan dengan total tahunan $29 \mathrm{~mm}$. Sebaliknya, selama 9 bulan (Agustus, dan November s.d Juni) surplus air cukup tingi, dengan kisaran 16 hingga 239 $\mathrm{mm}$ dengan total surplus $1124 \mathrm{~mm} / \mathrm{tahun}$; dimana surplus air tahunan akan meningkat sebesar $222 \%$ atau meningkat sebesar $775 \mathrm{~mm}$ dari kondisi normal, yaitu dari $349 \mathrm{~mm}$ menjadi $1124 \mathrm{~mm}$. Secara grafis periode surplus air tanah di Daerah Waeapo pada kondisi La Nina seperti yang disajikan pada Gambar 4.

\section{Periode Tumbuh Tersedia}

Hasil penentuan periode tumbuh tersedia pada tiga kondisi curah hujan rata-rata/normal, El Nino/ekstrem kering, dan La Nina/ekstrem basah seperti yang disajikan pada Tabel 8 .

Tabel 8 menunjukkan bahwa pada kondisi curah hujan normal rasio $\mathrm{CH} /$ Etp pada bulan Juli sebesar 0,58 dan Oktober 0,37 atau $\leq 0,75$ sehingga tidak masuk dalam periode tumbuh tersedia. Dengan demikian, periode tumbuh tersedia di Daerah Waeapo pada kondisi curah hujan normal berlangsung selama 8 bulan (November s.d Juni).

Ketika fenomena El-Nino berlangsung, periode tumbuh tersedia hanya selama 5 bulan (Januari s.d Mei). Pada bulan Juni rasio $\mathrm{CH} /$ Etp sebesar 0,27 atau $\leq 0,75$ sehingga tidak masuk dalam periode tumbuh tersedia. Selanjutnya, pada bulan Desember walaupun nilai rasio $\mathrm{CH} /$ Etp $\geq 0,75$ namun kandungan air tanah jauh berada dibawah kondisi optimumnya, yaitu hanya $169 \mathrm{~mm}$ yang nyaris sama dengan nilai titik layu permanen 167 mm. Dengan demikian, bulan Desember dipertimbangkan tidak masuk dalam periode tumbuh tersedia, karena pada bulan tersebut merupakan bulan terakhir dari akumulai air yang hilang secara potensial sehingga tidak ada penambahan cadangan air tanah.

Kejadian curah hujan ekstrem basah (La-Nina) di Daerah Waeapo akan berdampak pada meningkatnnya kadar air tanah; terutama selama musim kemarau, sehingga akan memperpanjang periode tumbuh. Pada kondisi curah hujan ini, periode tumbuh di wilayah ini berlangsung sepanjang tahun (12 bulan). Pada saat kejadian La-Nina terjadi penambahan panjang periode tumbuh selama 4 bulan (Juli s.d Oktober) dibandingkan kondisi normalnya.

Berdasarkan hasil penentuan periode tumbuh tersedia pada berbagai kondisi curah hujan tersebut, tabel berikut ini menyajikan kemungkinan intensitas tanam beberapa komoditi sayuran dan tanaman pangan utama di Daerah Waeapo; dimana intensitas tanam disamping bergantung pada panjangnya periode tumbuh yang tersedia tetapi juga umur panen masing-masing tanaman. Jenis komoditi sayuran dan tanaman pangan dimaksud adalah yang biasanya diusahakan petani di Daerah Waeapo dan kebutuhan airnya hanya bergantung pada hujan yang jatuh; meliputi tanaman pangan: jagung, ubi kayu, ubi jalar, kacang tanah, kacang hijau, dan kedelai serta tanaman sayuran: cabe, tomat, kubis, labu siam, terong, kacang panjang, dan buncis.

Tabel 8. Penentuan periode tumbuh tersedia di Daerah Waeapo pada berbagai kondisi curah hujan

\begin{tabular}{|c|c|c|c|c|c|c|c|c|c|c|c|c|}
\hline Komponen & Jan & Feb & Mar & Apr & Mei & Jun & Jul & Ags & Sep & Okt & Nov & Des \\
\hline \multicolumn{13}{|c|}{ Curah Hujan Normal (rata-rata) } \\
\hline \multicolumn{13}{|l|}{ Periode KATopt } \\
\hline \multicolumn{13}{|l|}{ Periode Tanpa Defisit Air } \\
\hline Rasio: CH/Etp & & & & & & & 0,58 & & & 0,37 & & \\
\hline \multicolumn{13}{|l|}{ Periode Tumbuh Tersedia } \\
\hline \multicolumn{13}{|c|}{ Curah Hujan Ekstrem Kering (El-Nino) } \\
\hline \multicolumn{13}{|l|}{ Periode KATopt } \\
\hline \multicolumn{13}{|l|}{ Periode Tanpa Defisit Air } \\
\hline Rasio: CH/Etp & & & & & & 0,27 & & & & & & 0,76 \\
\hline Periode Tumbuh Tersedia & & & & & & & & & & & & ???? \\
\hline \multicolumn{13}{|c|}{ Curah Hujan Ekstrem Basah (La-Nina) } \\
\hline \multicolumn{13}{|l|}{ Periode KATopt } \\
\hline \multicolumn{13}{|l|}{ Periode Tanpa Defisit Air } \\
\hline \multicolumn{13}{|l|}{ Rasio: $\mathrm{CH} / \mathrm{Etp}$} \\
\hline Periode Tumbuh Tersedia & & & & & & & & & & & & \\
\hline
\end{tabular}


Tabel 9. Intensitas tanam komoditi sayuran dan tanaman pangan di Daerah Waeapo pada berbagai kondisi curah hujan

\begin{tabular}{clc}
\hline $\begin{array}{c}\text { Umur Panen } \\
(\text { Bulan })\end{array}$ & \multicolumn{1}{c}{ Komoditi } & $\begin{array}{c}\text { Intensitas Tanaman } \\
\text { (Kali) }\end{array}$ \\
\hline & \multicolumn{1}{c}{ Kondisi Curah Hujan Nomal : Periode Tumbuh 8 Bulan } & 2 \\
3 & Jagung, Kacang Hijau, Kedelai & 4 \\
3 & Kacang Panjang, Cabe, Buncis, Terong, Kubis & 2 \\
4 & Ubi Jalar, Kacang Tanah, Kedelai, Labu Siam, Kubis & 2 \\
5 & Ubi Jalar, Labu Siam & 1 \\
$\geq 6$ & Ubi Kayu & 1 \\
3 & Kondisi Curah Hujan Ekstrim Kering (El-Nino) : Periode Tumbuh 5 Bulan & 1 \\
3 & Jagung, Kacang Hijau, Kedelai & 1 \\
4 & Kacang Panjang, Cabe, Buncis, Terong, Kubis & 1 \\
5 & Ubi Jalar, Kacang Tanah, Kedelai, Labu Siam, Kubis & 1 \\
\hline 6 & Ubi Jalar, Labu Siam & 3 \\
3 & Ubi Kayu & 6 \\
3 & Kondisi Curah Hujan Ekstrim Basah (La-Nina) : Periode Tumbuh 12 Bulan & 3 \\
4 & Jagung, Kacang Hijau, Kedelai & 3 \\
5 & Kacang Panjang, Cabe, Buncis, Terong, Kubis & 2 \\
\hline 6 & Ubi Jalar, Kacang Tanah, Kedelai, Labu Siam, Kubis & \\
\hline
\end{tabular}

\section{KESIMPULAN}

(1) Dalam periode 30 tahun terakhir (1988-2017) di Daerah Waeapo sudah terjadi fenomena curah hujan ekstrem kering atau El-Nino sebanyak 8 kali, yaitu pada tahun: 1991, 1994, 1997, 2002, 2004, 2006, 2009, dan 2015; intensitas 2-6 tahun sekali atau rata-rata 3 tahun sekali. Fenomena curah hujan ekstrem basah atau La-Nina terjadi sebanyak 6 kali, yaitu pada tahun: 1988, 1998, 2007, 2010, 2011, dan 2016; intensitas 1-10 tahun sekali atau rata-rata 5 tahun sekali.

(2) Berdasarkan perhitungan neraca air lahan, pada kondisi curah hujan ekstrem kering (El-Nino) terjadi defisit air tanah tahunan sebesar $403 \mathrm{~mm}$ atau $172 \%$ dari kondisi normalnya, yaitu dari 234 mm menjadi $637 \mathrm{~mm}$. Pada kondisi curah hujan ekstrem basah (La-Nina) terjadi surplus air tanah tahunan sebesar $775 \mathrm{~mm}$ atau $222 \%$ dari kondisi normalnya, yaitu dari $349 \mathrm{~mm}$ menjadi $1124 \mathrm{~mm}$.

(3) Pada kondisi curah hujan normal, periode tumbuh tersedia di Daerah Waeapo berlangsung selama 8 bulan (November s.d Juni). Ketika terjadi fenomena El-Nino periode tumbuh yang tersedia hanya 5 bulan (Januari s.d Mei), dan ketika terjadi fenomena La-Nina periode tumbuh berlangsung sepanjang tahun (12 bulan).

\section{DAFTAR PUSTAKA}

Boer, R., J.S. Baharsjah, I. Las dan H. Pawitan. 2003. Analisis kerentanan dan adaptasi terhadap keragaman dan perubahan iklim dalam Buku Panduan Simposium Meteorologi Pertanian VI: Anomali dan perubahan iklim sebagai peluang untuk meningkatkan hasil perikanan dan ketahanan pangan. PERHIMPI, Bogor.

[BPS] Badan Pusat Statistik. 2017. Buru Dalam Angka. BPS Kabupaten Buru, Namlea.

Kaimuddin. 2000. Dampak Perubahan Iklim dan Tataguna Lahan terhadap Keseimbangan Air Wilayah Saddang. [Disertasi]. PPs, IPB Bogor.

Kattenberg A, F. Giorgi, H. Grassi, G.A. Meehl, J.F.B. Mitchel, R.J. Stouffer, T. Tokioka, A.J. Weaver, and T.M.L. Wigley. 1976. Climate modelsprojections of future climate. pp.285-357 in Climate change 1994: Radiative forcing of climate change and an evaluation of the IPCC IS92 emission scenarios [Haoghton, JT., LG Meiro Filho, BA Callender, A Kattenberg and K Maskel (eds)]. Cambridge University Press, UK, 572 pp.

Laimeheriwa, S. 2015. Analisis Data Iklim Dalam Bidang Pertanian: Peluang Curah Hujan, Masa Tanam, Neraca Air Lahan dan Klasifikasi Iklim Wilayah. Bahan Ajar Agroklimatologi, Fakultas Pertanian Unpatti, Ambon.

Las, I. 2007. Pembingkaian Diskusi Panel dan Penelitian Konsorsium Perubahan Iklim. Presentasi Round Table Discussion. Tim Pokja Anomali Iklim. Badan Litbang Pertanian. Bogor.

Osok, R.M., P.J. Kunu, dan S. Laimeheriwa. 2017. Kajian Dampak Perubahan Iklim Terhadap Ketersediaan Air di Pulau Wamar Kabupaten Kepulauan Aru. Laporan Penelitian, Kerjasama dengan USAID, Jakarta.

Tim Amdal Unpatti. 2017. Studi Amdal Pemanfaatan Hasil Penataan dan Pemulihan Lingkungan pada Lokasi Bekas Pertambangan Tanpa Ijin (PETI) di Gunung Botak dan Gogrea Kabupaten Buru, Ambon. 